\section{Genetic assortment}

\author{
Jeffrey Williams
}

Molecular Genetics of Mammalian Cells: A Primer in Developmental Biology. Edited by George M. Malacinski. Macmillan New York/Collier Macmillan London:1987. Pp.389. \$52, £45.

PITy the plight of an editor of a volume such as this, which attempts to review a massive field of research where new insights and discoveries are accumulating at a dizzying rate. Given a finite limit to the length of the book, overall coverage will be patchy. Add in the normal delay between the time of writing and of publication, in a hardback, glossy format, and perspectives in certain areas will inevitably be outdated. In this particular collection of essays, the editors have compounded the former problem by including several chapters which deal solely with the work of a single group in what can be best described as bywaters of mammalian cell research. Thus the chapters on cell mutants in RNA polymerase II and on drug resistant dihydrofolate reductase genes are worthy but hardly merit the space devoted to them. The latter article could easily have been condensed to a single paragraph in the excellent review of dihydrofolate reductase gene amplification which follows it.

What makes this misuse of space particularly reprehensible, in a self-professed "Primer in Developmental Biology", is the almost complete absence of any discussion of developmental regulation of gene expression. Thus important differentiation-inducible systems, such as mouse erythroleukaemia or teratocarcinoma cell lines, are not described. In addition to inconsistency in the choice of subject, the individual articles vary enormously in depth of coverage and intellectual rigour. The chapter on housekeeping genes, and that on DNA methylation, are poorly written, uncritical and add nothing to previous reviews. In contrast two articles on hormone inducible genes, and a review of enhancer elements by the late George Khoury, are very worthy additions to the literature. Even this latter article is, however, but a starting point for further reading because it pre-dates the explosion of information concerning enhancer-binding proteins.

Given the rate of progress in this field, what is the role of such a book? If it is to be purely educational, then it probably will not be of great value. The beginner can read the new generation of text books, which are almost as comprehensive and up to date as some of these articles, and those with some background knowlege can consult the last few years' review pages from leading biological journals. The book does, however, have other stated aims, and in these it is successful. It adequately conveys, for the non-initiated, a sense of the mechanics and the power of the techniques involved and it highlights several potential applications of mammalian cell genetics, such as the production of commercially important proteins and the correction of human genetic diseases. Add to this the several worthwhile articles

\section{Bridge of size}

Henry Petroski

The Gate: The True Story of the Design and Construction of the Golden Gate Bridge. By John van der Zee. Simon \& Schuster: 1987. Pp.380. £14.95, \$19.95.

THE prehistory of a big engineering project can span decades and even centuries, but it is not because our dreams to build and manufacture must wait for our science to catch up. Innovative engineering, especially in the realization of dream bridges and dream machines, has often actually led science and revealed new phenomena of nature to be explained. The words and formulae of now-sophisticated sciences such as structural mechanics and thermodynamics came long after the often ineffable appearance of a grand new bridge carrying a grand new steam locomotive across a grand old expanse of water and air.

The greatest feats of engineering do not arise full blown out of equations; they arise out of imagination, and determination and perseverance. A bridge builder must first overcome not the intricacies of scientific analysis but the machinations of already mentioned and the book does merit inclusion in a departmental library with money left to spend at the end of the financial year. It would not, however, be one I would consider adding to my personal collection.

Jeffrey Williams is at the Clare Hall Laboratories, Imperial Cancer Research Fund, Blanche Lane, South Mimms, Potters Bar, Hertfordshire EN6 $3 L D, U K$.

ferry boat operators who would be left high and dry. He must answer the critics who say there is no firm riverbed on which to found his piers. He must answer the environmentalists who say his bridge will spoil the landscape. He must answer the Navy which says his bridge will impede their ships. And he must answer the engineers who say his design is technically not feasible. A bridge, then, is not a unique solution to a differential equation but a cultural and technological compromise.

The history of the origins, design, construction and continuing symbolic presence of the Brooklyn Bridge is archetypal, and it has been related by David McCullough in his book The Great Bridge (1972). Now John van der Zee has told the similarly compelling story of the Golden Gate Bridge on the occasion of the fiftieth anniversary of its opening. Neither author is an engineer, but both have mastered the technical details of their subjects. And both have used their talents as writers to narrate not only the technical but also the human drama involved in bringing the concept of a great bridge to fruition.

Engineering projects necessarily involve a large cast of characters, and van der Zee has portrayed his as deftly as a novelist might. The engineers in this book

\section{IMAGE UNAVAILABLE FOR COPYRIGHT REASONS}

California dreaming - the Golden Gate Bridge under construction. 